\title{
Anthropometric Characteristics, Body Composition and Somatotype of Elite Male Young Runners
}

\author{
Cristóbal Sánchez Muñoz ${ }^{1}$, José J. Muros ${ }^{2, * \mathbb{C}}$, Óscar López Belmonte ${ }^{1}$ and Mikel Zabala ${ }^{3}$ \\ 1 Department of Physical Education and Sport, University of Granada, 52071 Melilla, Spain; \\ csm@ugr.es (C.S.M.); oscarlobe195@gmail.com (Ó.L.B.) \\ 2 Department of Didactics of Musical, Plastic and Corporal Expression, University of Granada, \\ 18071 Granada, Spain \\ 3 Department of Physical Education and Sport, University of Granada, 18071 Granada, Spain; mikelz@ugr.es \\ * Correspondence: jjmuros@ugr.es
}

Received: 29 December 2019; Accepted: 19 January 2020; Published: 20 January 2020

check for updates

\begin{abstract}
The purpose of the present study was to describe the anthropometric characteristics, body composition and somatotype of elite male young runners (EYR), and to compare these variables according to the specialty in which they engaged (middle-distance vs. long-distance). This will enable an anthropometric profile chart to be established for them. Ninety EYR aged 17 to 23 years $(18.4 \pm 2.0)$ participated in the study. Athletes were divided into two groups according to the event in which they participated: middle-distance runners $(\mathrm{MDR}, \mathrm{n}=56)$ and long-distance runners (LDR, $\mathrm{n}=34$ ). Sixteen anthropometric variables were recorded for each participant: Weight, height, eight skinfolds, four girths, and two breadths. Body mass index (BMI), body composition and somatotype were calculated. Comparing MDR with the group of LDR, significant differences were found to exist for height, weight, relaxed upper arm girth, flexed and tensed upper arm girth, total upper arm area, upper arm muscle area, and thigh muscle area. No significant differences were observed in the other variables. MDR are taller, heavier and have larger girths than LDR. Coaches and sports scientists can use the data obtained to better control training, as well as for talent identification and athlete selection.
\end{abstract}

Keywords: anthropometry; body composition; somatotype; runners; youth

\section{Introduction}

In the last few years, issues that influence optimal performance in running events have received considerable attention in the scientific literature. Variables which have been associated with running performance include physical characteristics, maximal aerobic power $\left(\mathrm{VO}_{2 \mathrm{max}}\right)$ [1-5], body composition [5-7], thigh-length [6], lactate threshold [8], the energy cost of running [9-12], running economy $[10,13,14]$ and stride length $[15,16]$.

Several researchers have published the physical characteristics of different types of runners $[7,17,18]$. Many studies have shown the anthropometric characteristics, somatotype and body composition of elite male adult runners $[19,20]$. However, to our knowledge, only two studies [18,21] have described these aspects in young elite male runners (EYR), and few studies have reported data for both individual and the sum of skinfold values amongst runners [18,22-24].

A moderate relationship between BMI and marathon running performance has been reported by Dotan et al. [25]. Arrese and Ostáriz [26] also reported lower limb skinfold thicknesses in males to be directly related to running time over $1500 \mathrm{~m}$ and $10,000 \mathrm{~m}$. With regard to body composition, Brandon and Boileau [27] have reported that a larger fat-free mass enables runners to be more efficient. In addition, Wilson et al. [28] studied the relationship between somatotype and physical performance in running events. 
The aims of the present study were (1) to describe the anthropometric characteristics, body composition and somatotype of elite young runners (EYR), (2) to compare these variables according to participation in middle- or long-distance events, and (3) to establish an anthropometric profile chart for EYR.

\section{Materials and Methods}

\subsection{Subjects}

Ninety EYR aged 17 to 23 years old $(18.4 \pm 2.0)$ took part in the present study. All participants were national and international elite male runners. All participants were medalists in their aged category at the Spanish Championships, with fifteen of them being classified in the top ten at the European and World Championships. Runners were classified into two groups according to the event in which they participated: middle-distance (MDR, $\mathrm{n}=56)(800 \mathrm{~m}$ and $1500 \mathrm{~m})$ and long-distance (LDR, $\mathrm{n}=34)$ $(3000 \mathrm{~m}, 3000 \mathrm{~m}$ steeplechase and $5000 \mathrm{~m})$ running events. Prior to measurement, all runners aged over 18 years gave informed consent to participate in the study. Completed parental consent forms were obtained for runners who were younger than 18 years old prior to them participating in the present research. The same runner could have participated in a number of MDR events $(800 \mathrm{~m}$ or $1500 \mathrm{~m}$, or both), these events all belonging to the same group of events. The same can be seen with those who participated in LDR. Evaluations were conducted at different meetings organized by the Andalusian Athletics Federation over a number of years. For all runners, data collection took place during a single day. Performance results were noted from the individual records of each athlete during the period in which they attended various meetings of the Andalusian Athletic Federation. The study was approved by the Ethics Committee of the University of Granada $(n=883)$ and was carried out in compliance with the Declaration of Helsinki.

\subsection{Anthropometric Data}

Anthropometric measurements were performed following standardised techniques adopted by the International Society for the Advancement of Kinanthropometry (ISAK) [29] in basal conditions. This means that circumstances were avoided that affect the thickness and compressibility of skinfold measurements, such as previous exercise, baths, sauna sessions or dehydration states. Participants were measured barefoot, shirtless and were wearing shorts. All measurements were taken by the same investigator who was a Level 2 ISAK anthropometrist. Technical measurement error was lower than $5 \%$ for skinfolds and lower than $1 \%$ for all other measurements. Sixteen anthropometric variables were measured for each subject. These were: weight; height; thickness of 8 skinfolds (biceps, triceps, subscapular, suprailiac, supraspinal, abdominal, thigh and calf), 4 girths (relaxed upper arm, flexed and tensed upper arm, thigh and maximum calf), and 2 breadths (humerus and femur). Height was measured on a stadiometer to the nearest $0.1 \mathrm{~cm}$ (GPM, Seritex, Inc., Carlstadt, New Jersey) and body mass was recorded on a portable scale to the nearest $0.1 \mathrm{~kg}$ (model 707, Seca Corporation, Columbia, Maryland). Skinfold thickness was measured using a caliper calibrated to the nearest $0.2 \mathrm{~mm}$ (Holtain Ltd, Crymych, UK) and girths measurements were performed using a flexible anthropometric steel tape (Holtain Ltd, Crymych, UK) to the nearest $0.1 \mathrm{~cm}$. Skinfolds were measured three times and the median was used in analyses. The sum of 3 skinfolds (triceps, subscapular, and supraspinal), the sum of 6 skinfolds (sum of 3 skinfolds and suprailiac, abdominal and thigh) and the sum of 8 skinfolds (sum of 6 and biceps and medial calf) were also calculated. BMI was calculated as weight/height ${ }^{2}$, where body mass was expressed in kilograms $(\mathrm{kg})$ and height in metres $(\mathrm{m})$. Body density was estimated using the equations of Durnin and Womersley [30], Katch and McArdle [31], Sloan [32], Wilmore and Behnke [33], and Withers et al. [34]. Density was transformed to \%BF using Siri's equation [35]. Muscle mass (MM) was determined in $\mathrm{kg}$ using the methods of Lee et al. [36]. Somatotype was determined using the Heath-Carter anthropometric method [37]. Performance was determined according to the time obtained in the race event in which athletes participated. 


\subsection{Statistical Analyses}

Standard descriptive statistics such as mean and standard deviation were used to present participant characteristics for all variables. The nonparametric Mann-Whitney test was used to compare anthropometric data between MDR and LDR groups. Statistical significance was set at $p<0.05$. A profile chart was developed according to norms derived from percentiles $(5=$ lowest; $95=$ highest). All statistical analyses were performed using the Statistical Package for the Social Sciences (version 21.0; SPSS, Inc, Chicago, IL, USA).

\section{Results}

Tables 1 and 2 show the characteristics of the study sample and the results from the statistical analysis for differences between MDR and LDR. Mean height and weight of the assessed participants were $174.8 \pm 4.7 \mathrm{~cm}$ and $61.8 \pm 5.8 \mathrm{~kg}$, respectively, with MDR being significantly taller and heavier than LDR ( $p=0.010$ and $p=0.002$, respectively). In addition, we did not find significant differences in BMI between MDR and LDR. In relation to all girth and breadth measures, MDR had significantly higher relaxed upper arm girths and flexed and tensed upper arm girths than LDR $(p=0.046 ; p=0.033$, respectively). No significant differences were observed between MDR and LDR for the remaining girth and breadth measurements, skinfolds sums or \%BF.

Table 1. Demographic characteristics of the study sample (mean \pm SD) and differences between middle-distance runners and long-distance runners.

\begin{tabular}{|c|c|c|c|}
\hline Dimension & Total Runners $(\mathrm{N}=90)$ & Middle-Distance Runners $(n=56)$ & Long-Distance Runners $(\mathrm{n}=34)$ \\
\hline & Mean \pm SD & Mean \pm SD & Mean \pm SD \\
\hline Age (yr.) & $18.4 \pm 2.0$ & $18.3 \pm 2.1$ & $18.3 \pm 1.9$ \\
\hline Height (cm) & $174.8 \pm 4.7$ & $175.2 \pm 4.7$ & $174.1 \pm 4.6$ \\
\hline Weight (kg) & $61.8 \pm 5.6$ & $62.4 \pm 5.3$ & $60.7 \pm 5.9$ \\
\hline $\mathrm{BMI}\left(\mathrm{kg} / \mathrm{m}^{2}\right)$ & $20.2 \pm 1.5$ & $20.3 \pm 1.5$ & $20.0 \pm 1.6$ \\
\hline Total years running (yr.) & $6.2 \pm 2.0$ & $6.2 \pm 2.1$ & $6.1 \pm 1.9$ \\
\hline Training (hours/week) & $12.2 \pm 4.3$ & $12.1 \pm 4.4$ & $12.5 \pm 4.2$ \\
\hline Performance (min:sec) & - & $\begin{array}{l}1: 53.9 \pm 4.2^{\mathrm{a}} \\
3: 53.6 \pm 8.8^{\mathrm{b}}\end{array}$ & $\begin{array}{c}8: 22.2 \pm 16.0^{\mathrm{c}} \\
14: 49.3 \pm 23.8^{\mathrm{d}} \\
9: 12.1 \pm 23.1^{\mathrm{e}}\end{array}$ \\
\hline
\end{tabular}

${ }^{a}$ record $800 \mathrm{~m} ;{ }^{b}$ record $1500 \mathrm{~m} ;{ }^{c}$ record $3000 \mathrm{~m} ;{ }^{d}$ record $5000 \mathrm{~m} ;{ }^{e}$ record $3000 \mathrm{~m}$ steeplechase.

Table 2. Anthropometric characteristics, body composition and somatotype for young elite runners, (mean $\pm \mathrm{SD}$ ) and differences between middle-distance and long-distance runners.

\begin{tabular}{|c|c|c|c|c|}
\hline Dimension & $\begin{array}{l}\text { Total Runners } \\
\quad(\mathbf{N}=90)\end{array}$ & $\begin{array}{l}\text { Middle-Distance } \\
\text { Runners }(n=56)\end{array}$ & $\begin{array}{l}\text { Long-Distance } \\
\text { Runners }(n=34)\end{array}$ & $p$ \\
\hline & Mean $\pm S D$ & Mean \pm SD & Mean \pm SD & \\
\hline \multicolumn{5}{|l|}{ Skinfold thickness (mm) } \\
\hline Triceps $(\mathrm{mm})$ & $6.2 \pm 1.4$ & $6.2 \pm 1.2$ & $6.2 \pm 1.6$ & NS \\
\hline Biceps (mm) & $3.0 \pm 0.5$ & $3.0 \pm 0.5$ & $3.1 \pm 0.5$ & NS \\
\hline Subscapular (mm) & $7.1 \pm 1.1$ & $7.2 \pm 1.0$ & $7.0 \pm 1.2$ & NS \\
\hline Suprailiac (mm) & $8.0 \pm 2.2$ & $7.9 \pm 2.2$ & $8.2 \pm 2.2$ & NS \\
\hline Supraspinal (mm) & $4.9 \pm 1.2$ & $4.9 \pm 1.3$ & $5.0 \pm 1.1$ & NS \\
\hline Abdominal (mm) & $7.6 \pm 2.1$ & $7.6 \pm 1.9$ & $7.7 \pm 2.3$ & NS \\
\hline Thigh (mm) & $8.5 \pm 2.3$ & $8.2 \pm 2.1$ & $8.9 \pm 2.6$ & NS \\
\hline Calf (mm) & $5.6 \pm 1.3$ & $5.5 \pm 1.1$ & $5.9 \pm 1.5$ & NS \\
\hline \multicolumn{5}{|l|}{ Girth $(\mathrm{cm})$} \\
\hline Upper arm girth $(\mathrm{cm})^{a}$ & $25.6 \pm 1.5$ & $25.8 \pm 1.5$ & $25.2 \pm 1.5$ & 0.046 * \\
\hline Upper arm girth $(\mathrm{cm})^{b}$ & $28.3 \pm 1.5$ & $28.5 \pm 1.4$ & $27.8 \pm 1.5$ & 0.033 * \\
\hline Thigh girth $(\mathrm{cm})$ & $48.8 \pm 2.9$ & $49.3 \pm 2.9$ & $48.1 \pm 2.8$ & NS \\
\hline Calf girth (maximum) $(\mathrm{cm})$ & $35.6 \pm 1.8$ & $35.7 \pm 1.9$ & $35.4 \pm 1.7$ & NS \\
\hline \multicolumn{5}{|l|}{ Breadth (cm) } \\
\hline Humerus $(\mathrm{cm})$ & $6.5 \pm 0.3$ & $6.5 \pm 0.3$ & $6.5 \pm 0.4$ & NS \\
\hline Femur $(\mathrm{cm})$ & $9.5 \pm 0.4$ & $9.5 \pm 0.4$ & $9.5 \pm 0.4$ & NS \\
\hline
\end{tabular}


Table 2. Cont.

\begin{tabular}{|c|c|c|c|c|}
\hline Dimension & $\begin{array}{l}\text { Total Runners } \\
\quad(\mathrm{N}=90)\end{array}$ & $\begin{array}{l}\text { Middle-Distance } \\
\text { Runners }(\mathrm{n}=56)\end{array}$ & $\begin{array}{l}\text { Long-Distance } \\
\text { Runners }(\mathrm{n}=34)\end{array}$ & $p$ \\
\hline & Mean \pm SD & Mean \pm SD & Mean \pm SD & \\
\hline \multicolumn{5}{|l|}{ Sum of skinfolds (mm) } \\
\hline Sum of 3 skinfolds (mm) & $21.4 \pm 3.7$ & $21.3 \pm 3.5$ & $21.5 \pm 4.0$ & NS \\
\hline Sum of 6 skinfolds (mm) & $45.5 \pm 8.4$ & $45.0 \pm 8.4$ & $46.4 \pm 9.4$ & NS \\
\hline Sum of 8 skinfolds (mm) & $54.2 \pm 9.7$ & $53.5 \pm 9.3$ & $55.3 \pm 10.5$ & NS \\
\hline Sum upper limb skinfolds (mm) & $37.0 \pm 6.7$ & $36.8 \pm 6.5$ & $37.2 \pm 7.1$ & NS \\
\hline Sum lower limb skinfolds (mm) & $14.1 \pm 3.3$ & $13.7 \pm 2.9$ & $14.8 \pm 3.8$ & NS \\
\hline \multicolumn{5}{|l|}{ Body fat $(\%)$} \\
\hline Durnin and Womersley [30] & $11.0 \pm 2.3$ & $11.0 \pm 2.2$ & $11.1 \pm 2.5$ & NS \\
\hline Katch and McArdle [31] & $7.5 \pm 1.1$ & $7.5 \pm 1.0$ & $7.5 \pm 1.2$ & NS \\
\hline Sloan [32] & $6.8 \pm 1.6$ & $6.7 \pm 1.4$ & $7.0 \pm 1.8$ & NS \\
\hline Wilmore and Behnke [33] & $10.4 \pm 1.0$ & $10.3 \pm 0.9$ & $10.4 \pm 1.1$ & NS \\
\hline Withers et al. [34] & $7.7 \pm 1.2$ & $7.6 \pm 1.1$ & $7.8 \pm 1.3$ & NS \\
\hline Skeletal muscle mass (kg) [36] & $48.2 \pm 2.3$ & $48.3 \pm 2.0$ & $48.0 \pm 2.8$ & NS \\
\hline \multicolumn{5}{|l|}{ Area $\left(\mathrm{cm}^{2}\right)$} \\
\hline Total upper arm area $\left(\mathrm{cm}^{2}\right)$ & $52.2 \pm 6.2$ & $53.2 \pm 6.1$ & $50.5 \pm 6.0$ & $0.046^{*}$ \\
\hline Upper arm muscle area $\left(\mathrm{cm}^{2}\right)$ & $46.4 \pm 5.6$ & $47.4 \pm 5.5$ & $44.9 \pm 5.6$ & 0.038 * \\
\hline Upper arm fat area $\left(\mathrm{cm}^{2}\right)$ & $5.8 \pm 1.2$ & $5.8 \pm 1.1$ & $5.7 \pm 1.2$ & NS \\
\hline Total thigh area $\left(\mathrm{cm}^{2}\right)$ & $190.5 \pm 22.7$ & $193.8 \pm 23.0$ & $185.0 \pm 21.5$ & NS \\
\hline Thigh muscle area $\left(\mathrm{cm}^{2}\right)$ & $170.4 \pm 21.9$ & $174.1 \pm 21.3$ & $164.2 \pm 21.8$ & 0.039 \\
\hline Thig fat area $\left(\mathrm{cm}^{2}\right)$ & $20.1 \pm 5.5$ & $19.7 \pm 5.3$ & $20.8 \pm 5.9$ & NS \\
\hline \multicolumn{5}{|l|}{ Somatotype } \\
\hline Endomorphy & $1.7 \pm 0.4$ & $1.7 \pm 0.4$ & $1.7 \pm 0.4$ & NS \\
\hline Mesomorphy & $3.8 \pm 0.9$ & $3.8 \pm 0.9$ & $3.7 \pm 0.9$ & NS \\
\hline Ectomorphy & $3.8 \pm 0.9$ & $3.8 \pm 0.9$ & $3.9 \pm 0.9$ & NS \\
\hline
\end{tabular}

An anthropometric profile chart was developed to evaluate the physical characteristics of young male runners (Table 3). In this profile, we can derive an overall evaluation of the physical characteristics of participants. The chart is useful as a screening device though all interpretations must be made in consideration of the specific individual context.

Table 3. Anthropometric profile chart for young elite runners $(\mathrm{N}=90)$.

\begin{tabular}{|c|c|c|c|c|c|c|c|}
\hline \multirow{2}{*}{ Dimension } & \multicolumn{7}{|c|}{ Percentiles } \\
\hline & 5 & 10 & 25 & 50 & 75 & 90 & 95 \\
\hline Height $(\mathrm{cm})$ & 167.5 & 168.9 & 172.0 & 174.6 & 178.0 & 181.0 & 182.7 \\
\hline Weight (kg) & 51.2 & 54.9 & 58.1 & 62.0 & 64.7 & 70.5 & 72.0 \\
\hline $\operatorname{BMI}\left(\mathrm{kg} / \mathrm{m}^{2}\right)$ & 17.4 & 18.2 & 19.2 & 20.2 & 21.2 & 22.3 & 22.7 \\
\hline Triceps skinfold (mm) & 4.1 & 4.5 & 5.4 & 6.2 & 7.1 & 8.0 & 8.5 \\
\hline Biceps skinfold (mm) & 2.0 & 2.5 & 2.7 & 3.0 & 3.4 & 3.7 & 3.9 \\
\hline Subscapular skinfold (mm) & 5.4 & 5.6 & 6.2 & 7.3 & 8.0 & 8.4 & 8.6 \\
\hline Suprailiac skinfold (mm) & 5.0 & 5.4 & 6.4 & 7.7 & 9.3 & 11.3 & 12.4 \\
\hline Supraspinal skinfold (mm) & 3.5 & 3.5 & 4.2 & 4.6 & 5.7 & 6.3 & 7.1 \\
\hline Abdominal skinfold (mm) & 5.0 & 5.3 & 6.3 & 7.3 & 8.6 & 10.5 & 12.4 \\
\hline Thigh skinfold (mm) & 5.0 & 5.4 & 7.0 & 8.0 & 9.7 & 11.6 & 13.7 \\
\hline Calf skinfold (mm) & 3.8 & 4.0 & 4.9 & 5.5 & 6.3 & 7.3 & 7.8 \\
\hline Upper arm girth $(\mathrm{cm})^{a}$ & 23.0 & 23.7 & 24.5 & 25.5 & 26.7 & 27.8 & 28.0 \\
\hline Upper arm girth $(\mathrm{cm})^{b}$ & 25.3 & 26.5 & 27.2 & 28.3 & 29.4 & 30.2 & 30.5 \\
\hline Thigh girth $(\mathrm{cm})$ & 43.5 & 45.1 & 47.0 & 49.0 & 51.2 & 52.5 & 53.4 \\
\hline Calf girth (maximum) $(\mathrm{cm})$ & 32.3 & 33.1 & 34.3 & 35.7 & 37.1 & 38.0 & 38.6 \\
\hline Humerus breadth (cm) & 6.0 & 6.1 & 6.3 & 6.6 & 6.8 & 7.0 & 7.0 \\
\hline Femur breadth $(\mathrm{cm})$ & 8.9 & 8.9 & 9.2 & 9.5 & 9.8 & 10.1 & 10.3 \\
\hline
\end{tabular}

${ }^{a}$ Relaxed; ${ }^{b}$ Flexed and tensed. 
The mean somatotype for evaluated EYR could be defined as ecto-mesomorphic (1.7-3.8-3.8). No significant differences were found in somatotype components between MDR and LDR $(p<0.05)$. Figure 1 presents a somatochart for young elite runners overall.

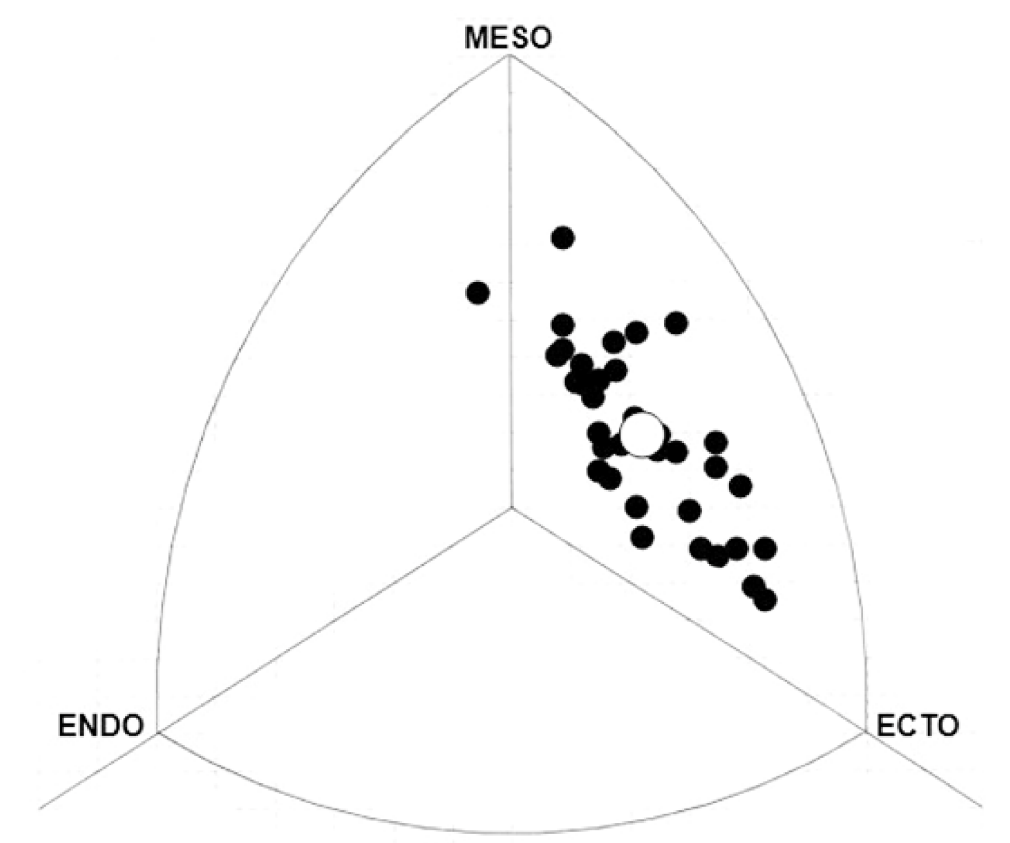

Figure 1. Somatotype distribution seen in young elite runners $(n=90) . O=$ mean somatotype $=$ 1.7-3.8-3.8 (endomorph, mesomorph, ectomorph).

\section{Discussion}

In agreement with Legaz Arrese et al. [18], the present results show that elite young MDR are taller and heavier than LDR. MDR also have larger girth and breadth dimensions. We were unable to find a similar study that compared the anthropometric characteristics of young elite male MDR and LDR. A comparison of the age, height, weight, BMI, \%BF and performance of male junior $[21,38,39]$ and senior $[1,5,6,19,24,40-44]$ runners participating in different events is given in Table 4 . The mean height of young male runners varies between 178 and $179 \mathrm{~cm}$, with this being similar to that seen in senior MDR (177-178 cm). On the other hand, senior male MDR and LDR appear to be heavier than junior male runners. Our group of young male MDR is on average $2.6 \mathrm{~cm}$ smaller and $0.6 \mathrm{~kg}$ heavier than the young male runners evaluated in other studies. Further, our group of young male LDR is on average $4.2 \mathrm{~cm}$ smaller and $2.9 \mathrm{~kg}$ lighter than other examined young male runners.

In relation to skinfold thickness, our results indicated that no significant differences are present between MDR and LDR in the sum of skinfolds. In agreement with Legaz et al. [18], this result may be due to the fact that both groups of runners engage in a similar training volume. The skinfold values found in our runners are higher than values reported in other studies $[18,45]$, except for the subscapular skinfolds of MDR which was lower. In comparison to Olympic runners [20], young runners involved in the present study had higher values for all skinfolds (except for subscapular skinfold) and the sum of six skinfolds. Only a handful of studies have reported data for individual skinfolds and the sum of values in relation to athletes of different ages [22,41,45]. Legaz et al. [18] found differences in the sum of six skinfolds between runners taking part in different events, but the present study did not find similar differences between MDR and LDR. The present study showed differences in upper arm girth, upper arm area, upper arm muscle area and thigh muscle area. The causes for such differences could be due to the type of training engaged in and subsequent nutrition strategy. Longer events typically need longer workouts and, therefore, a lower protein intake than events conducted over shorter distances. Performance over longer distances is also more dependent upon efficiency 
rather than efficacy, with lower muscle mass, especially in the upper limb, being key for this purpose. This makes sense as training is based on the quest for performance outcomes during competition. Longer distance events require athletes to be lighter and more efficient. This is achieved through a combination of their genetics, and training and nutritional strategies.

On the other hand, no significant differences were found in somatotype components between MDR and LDR. Carter [45] found that male Olympic runners were defined as ecto-mesomorphic (1.5-4.3-3.6 for MDR; 1.4-4.2-3.7 for LDR; and 1.4-4.4-3.4 for marathon runners), with no significant differences existing between Olympic runners taking part in different events. In accordance with previous studies [20], the mean somatotype of EMJR evaluated in the present study could also be defined as ecto-mesomorphic. When comparing the somatotype component values of young elite male MDR and LDR in the present study, with the somatotype component values of Olympic runners, young runners are seen to have somewhat higher endomorphy and ectomorphy values, and lower mesomorphy values.

All information pertaining to the anthropometrical characteristics, body composition and somatotype of Spanish elite junior runners, provides a frame of reference that can be used by coaches to better control the training process for the improvement of athlete performance and detect talent in running disciplines. All of these physical factors should be considered alongside performance, physiological, psychological and technical factors. 
Table 4. Summary table of studies examining age, height, weight, BMI, \%BF and performance of elite runners participating in different events (mean \pm SD).

\begin{tabular}{|c|c|c|c|c|c|c|c|c|}
\hline Study & $\mathbf{n}$ & Age (year) & Height (cm) & Weight (kg) & BMI $\left(k g / m^{2}\right)$ & BF (\%) & Time (s) & Event \\
\hline Billat et al. [38] & 8 & $18.0 \pm 1.0$ & $179.0 \pm 4.0$ & $62.0 \pm 7.0$ & - & $9.0 \pm 1.5^{b}$ & $\begin{array}{c}800 \mathrm{~m}: 112.5 \pm 3.8 \\
1500 \mathrm{~m}: 235.3 \pm 6.7\end{array}$ & MD \\
\hline Housh et al. [21] & 26 & $17.3 \pm 0.8$ & $178.2 \pm 6.8$ & $63.6 \pm 6.3$ & - & - & - & MD \\
\hline Kenney and Hodgson [39] & $\begin{array}{l}8 \\
5\end{array}$ & $\begin{array}{l}21.4 \pm 1.0 \\
22.0 \pm 1.5\end{array}$ & - & $\begin{array}{l}64.5 \pm 2.4 \\
71.9 \pm 1.0\end{array}$ & - & $\begin{array}{l}8.8 \pm 0.8 \\
9.2 \pm 0.5\end{array}$ & $5000 \mathrm{~m}: 845.0$ & LD \\
\hline Billat et al. [19] & 5 & $33.4 \pm 2.0$ & $172.0 \pm 2.0$ & $60.2 \pm 2.9$ & - & $\begin{array}{l}-.0 \\
-\end{array}$ & - & Marathon \\
\hline Billat et al. [40] & 13 & $26.5 \pm 3.6$ & $170.0 \pm 4.0$ & $53.8 \pm 4.7$ & - & $6.6 \pm 1.1^{b}$ & - & LD \\
\hline Brandon and Boileau [6] & 56 & $26.6 \pm 4.5$ & $179.5 \pm 6.5$ & $71.1 \pm 8.2$ & - & $13.7 \pm 4.6^{a}$ & $\begin{array}{c}800 \mathrm{~m}: 141.0 \\
1500 \mathrm{~m}: 291.0 \\
3000 \mathrm{~m}: 637.0\end{array}$ & MD \\
\hline Deason et al. [5] & 11 & $\begin{array}{l}30.0 \pm 3.9 \\
21.8 \pm 3.3\end{array}$ & $177.5 \pm 7.0$ & $\begin{array}{l}71.6 \pm 8.0 \\
69.3 \pm 4.9\end{array}$ & - & - & $\begin{array}{l}800 \mathrm{~m}: 132.6 \pm 7.3 \\
800 \mathrm{~m}: 109.7\end{array}$ & $800 \mathrm{~m}$ \\
\hline Legaz and Eston [41] & $\begin{array}{c}23 \\
16 \\
8\end{array}$ & $\begin{array}{l}22.9 \pm 3.2 \\
22.0 \pm 3.2 \\
27.5 \pm 4.1 \\
26.0 \pm 4.2 \\
30.5 \pm 3.9\end{array}$ & $\begin{array}{l}- \\
- \\
-\end{array}$ & $\begin{array}{l}65.7 \pm 3.9 \\
66.1 \pm 3.7 \\
60.7 \pm 4.2 \\
58.0 \pm 5.2 \\
59.9 \pm 3.3\end{array}$ & $\begin{array}{l}- \\
- \\
-\end{array}$ & $\begin{array}{l}- \\
- \\
-\end{array}$ & $\begin{array}{c}1500 \mathrm{~m}: 223.3 \\
3000 \mathrm{~m} \text { steepl.: } 518.8 \\
5000 \mathrm{~m}: 810.7 \\
\text { 10,000 m: } 1737.1 \\
\text { Marathon: } 7980.3\end{array}$ & $\begin{array}{l}\text { MD } \\
\text { LD }\end{array}$ \\
\hline Maldonado-Martin et al. [1] & 17 & $28.0 \pm 5.0$ & $178.0 \pm 7.0$ & $64.3 \pm 7.0$ & - & $12.4 \pm 1.8^{c}$ & $\begin{array}{c}\text { 1500: } 226.0 \pm 4.2 \\
\text { Marathon: } 8638.0 \pm 401.6\end{array}$ & $1500 \mathrm{~m} /$ Marathon \\
\hline Oguri et al. [42] & 11 & $61.4 \pm 3.0$ & $165.4 \pm 3.5$ & $59.4 \pm 4.9$ & $21.8 \pm 1.8$ & - & - & LD \\
\hline Pollock et al. [24] & 20 & - & $177.0 \pm 6.0$ & $63.1 \pm 4.8$ & - & $8.8 \pm 0.8$ & - & LD \\
\hline $\begin{array}{l}\text { Pollock et al. [43] } \\
\text { Vernillo et al. [44] }\end{array}$ & $\begin{array}{c}40-49 \\
14\end{array}$ & $\begin{array}{c}- \\
27.7 \pm 3.75 \\
\end{array}$ & $\begin{array}{c}180.7 \\
171.2 \pm 6.1\end{array}$ & $\begin{array}{c}63.1 \\
57.7 \pm 4.0\end{array}$ & - & $\begin{array}{c}8.8 \pm 0.8 \\
8.87 \pm 0.07^{d}\end{array}$ & $\begin{array}{c}- \\
\text { Marathon: } 7636.0 \pm 115.0\end{array}$ & $\begin{array}{c}\text { LD } \\
\text { Marathon }\end{array}$ \\
\hline Present study & $\begin{array}{l}90 \\
56 \\
34\end{array}$ & $\begin{array}{l}18.4 \pm 2.0 \\
18.3 \pm 2.1 \\
18.3 \pm 1.9\end{array}$ & $\begin{array}{l}174.8 \pm 4.7 \\
175.2 \pm 4.7 \\
174.1 \pm 4.6\end{array}$ & $\begin{array}{l}61.8 \pm 5.6 \\
62.4 \pm 5.3 \\
60.7 \pm 5.9\end{array}$ & $\begin{array}{l}20.2 \pm 1.5 \\
20.3 \pm 1.5 \\
20.0 \pm 1.6\end{array}$ & $\begin{array}{c}11.0 \pm 2.3^{b} / 7.5^{f} \pm 1.1^{e} \\
6.8 \pm 1.6^{f} / 10.4 \pm 1.0^{g} \\
7.7^{g} \pm 1.2^{h} \\
11.0 \pm 2.2^{b} / 7.5^{\prime} \pm 1.0^{e} \\
6.7 \pm 1.4^{f} / 10.3 \pm 0.9^{g} \\
7.6^{\prime} \pm 1.1^{h} \\
11.1 \pm 2.5^{b} / 7.5 \pm 1.2^{e} \\
7.0 \pm 1.8^{f} / 10.4 \pm 1.1^{g} \\
7.8^{g} \pm 1.3^{h}\end{array}$ & $\begin{array}{c}800 \mathrm{~m}: 113.9 \pm 4.2 \\
1500 \mathrm{~m}: 233.6 \pm 8.8 \\
3000 \mathrm{~m}: 502.2 \pm 16.0 \\
5000 \mathrm{~m}: 889.3 \pm 23.8 \\
3000 \mathrm{~m} \text { steeplechase: } 552.1 \pm 23.1\end{array}$ & $\begin{array}{c}\mathrm{MD} / \mathrm{LD} \\
800 \mathrm{~m} / 1500 \mathrm{~m} \\
3000 \mathrm{~m} / 5000 \mathrm{~m} \\
3000 \mathrm{~m} \\
\text { steeplechase }\end{array}$ \\
\hline
\end{tabular}

${ }^{a}$ Brozek et al. [46]; ${ }^{b}$ Durnin and Womersley [30] ${ }^{c}$ Durnin and Ramahan [47]; ${ }^{d}$ Jackson and Pollock [48]; ${ }^{e}$ Katch and McArdle [31]; ${ }^{f}$ Sloan [32]; ${ }^{g}$ Wilmore and Behnke [33] ${ }^{h}$ Withers et al. [34]. MD = Middle-distance running; LD = Long-distance running; - = Data not available. 


\section{Conclusions}

The present study provides reference values for anthropometric characteristics, body composition and somatotype of Spanish EYR in general, and MDR and LDR in particular. When comparing MDR with the group of LDR, significant differences were found to exist in height, weight, relaxed upper arm girth, flexed and tensed upper arm girth, total upper arm area, upper arm muscle area, and thigh muscle area. MDR could be defined as being more heavily built than LDR. Young Spanish elite male MDR are taller and heavier, with greater girth dimensions.

This study provides normative data that could help coaches with talent identification of young elite MDR and LDR.

Strengths: The main strength of the present study is the high quality of the studied participants. All were national and international elite male runners who were medalists in their age category at the Spain Championships. Fifteen of these were also classified in the top ten at the European and World Championships.

Limitations: Limitations of the present study include its cross-sectional design, which prevents conclusions from being made about the direction of associations. Results provide a frame of reference but should not be used as a fixed model for better performance. In this way, the results presented can be used as a standard reference but should be interpreted with caution in the context of individual characteristics and needs. Further, the chronological age of runners was considered instead of biological age. Thus, it is possible that some runners had not yet reached their maximum maturation levels and that differences exist in this aspect between runners.

Author Contributions: Conceptualization, C.S.M., M.Z.; Investigation, C.S.M., J.J.C., Ó.L.B., and M.Z.; Methodology, C.S.M. and J.J.M.; Supervision, M.Z.; Writing-original draft, C.M.S. and J.J.M.; Writing-review \& editing, C.S.M., J.J.M., Ó.L.B., and M.Z. All authors have read and agreed to the published version of the manuscript. Funding: This research received no external funding.

Acknowledgments: The authors would like to thank the Andalusian Athletics Federation for their permission to set up this study and for their full support and collaboration during the investigation. The authors also wish to thank all runners for their participation and cooperation in this study, and Francisco B. Ortega Porcel for his technical support.

Conflicts of Interest: The authors have no conflicts of interest with regard to this research.

\section{References}

1. Maldonado-Martin, S.; Mujika, I.; Padilla, S. Physiological variables to use in the gender comparison in highly trained runners. J. Sports Med. Phys. Fit. 2004, 44, 8-14.

2. Bassett, D.R.; Howley, E.T. Limiting factors for maximum oxygen uptake and determinants of endurance performance. Med. Sci. Sports Exerc. 2000, 32, 70-84. [CrossRef] [PubMed]

3. Billat, V.; Beillot, J.; Jan, J.; Rochcongar, P.; Carre, F. Gender effect on the relationship of time limit at $100 \%$ VO2max with other bioenergetic characteristics. Med. Sci. Sports Exerc. 1996, 28, 1049-1055. [CrossRef] [PubMed]

4. Brandsford, D.R.; Howley, E.T. Oxygen cost of running in trained and untrained men and women. Med. Sci. Sports 1977, 9, 41-44.

5. Deason, J.; Powers, S.K.; Lawyer, J.; Ayers, D.; Stuart, M.K. Physiological correlates to 800 meter running performance. J. Sports Med. Phys. Fit. 1991, 31, 499-504.

6. Brandon, L.J.; Boileau, R.A. Influence of metabolic, mechanical and physique variables on middle distance running. J. Sports Med. Phys. Fit. 1992, 32, 1-9.

7. Carter, J.E.L. (Ed.) Body composition of athletes. In Physical Structure of Olympic Athletes. Part I; Karger: Basel, Switzerland, 1982; pp. 107-116.

8. Farrell, P.A.; Wilmore, J.H.; Coyle, E.F.; Billing, J.E.; Costill, D.L. Plasma lactate accumulation and distance running performance. Med. Sci. Sports 1979, 11, 338-344. [CrossRef] 
9. Abe, D.; Yanagawa, K.; Yamanobe, K.; Tamura, K. Assessment of middle-distance running performance in sub-elite young runners using energy cost of running. Eur. J. Appl. Physiol. Occup. Physiol. 1988, 77, 320-325. [CrossRef]

10. Daniels, J.; Daniels, N. Running economy of elite male and elite female runners. Med. Sci. Sports Exerc. 1992, 24, 483-489. [CrossRef]

11. Joyner, M.J. Physiological limiting factors and distance running: Influence of gender and age on record performances. Exerc. Sport Sci. Rev. 1993, 21, 103-133. [CrossRef]

12. Maldonado, S.; Mujika, I.; Padilla, S. Influence of body mass and height on the energy cost of running in highly trained middle and long-distance runners. Int. J. Sports Med. 2002, 23, 268-272. [CrossRef] [PubMed]

13. Conley, D.L.; Krahenbuhl, G.S. Running economy and distance running performance of highly trained athletes. Med. Sci. Sports Exerc. 1980, 12, 357-360. [CrossRef] [PubMed]

14. Sjödin, B.; Svedenhag, J. Applied physiology of marathon running. Sports Med. 1985, 2, 83-99. [CrossRef] [PubMed]

15. Heinert, L.; Serfass, R.C.; Stull, G.A. Effect of stride length variation on oxygen uptake during level and positive grade treadmill running. Res. Q. Exerc. Sport 1988, 59, 127-130. [CrossRef]

16. Cureton, K.J.; Boileau, R.A.; Lohman, T.G.; Misner, J.E. Determinants of distance running performance in children: Analysis of a path model. Res. Q. 1977, 48, 270-279.

17. Khosla, T. Standards on age, height and weight in Olympic running events for men. Br. J. Sports Med. 1978, 12, 97-101. [CrossRef]

18. Legaz Arrese, A.; González Badillo, J.J.; Serrano Ostáriz, E. Differences in skinfold thicknesses and fat distribution among top-class runners. J. Sports Med. Phys. Fit. 2005, 45, 512-517.

19. Billat, V.L.; Demarle, A.; Slawinski, J.; Paiva, M.; Koralsztein, J.P. Physical and training characteristics of top-class marathon runners. Med. Sci. Sports Exerc. 2001, 33, 2089-2097. [CrossRef]

20. Carter, J.E.L. (Ed.) Skinfolds and Body Composition of Olympic Athletes. In Physical Structure of Olympic Athletes. Part II Kinanthropometry of Olympic Athletes; Karger: Basel, Switzerland, 1984; pp. 144-182.

21. Housh, T.J.; Thorland, W.G.; Johnson, G.O.; Tharp, G.D. Body build and composition variables as discriminators of sports participation of elite adolescent male athletes. J. Sports Med. Phys. Fit. 1984, 24, 169-174. [CrossRef]

22. Bosch, A.N.; Goslin, B.R.; Noakes, T.D.; Dennis, S.C. Physiological differences between black and white runners during a treadmill marathon. Eur. J. Appl. Physiol. Occup. Physiol. 1990, 61, 68-72. [CrossRef]

23. Graves, J.E.; Pollock, M.L.; Sparling, P.B. Body composition of elite female distance runners. Int. J. Sports Med. 1987, 8, 96-102. [CrossRef] [PubMed]

24. Pollock, M.L.; Gettman, R.; Jackson, A.; Ayres, J.; Ward, A.; Linnerud, A.C. Body composition of elite class distance runners. Part I: Cardiorespiratory aspects. Ann. NY Acad. Sci. 1977, 301, 361-370. [CrossRef] [PubMed]

25. Dotan, R.; Rotstein, R.; Dlin, R.; Inbar, O.; Kofman, H.; Kaplansky, Y. Relationships of marathon running to physiological, anthropometric and training indices. Eur. J. Appl. Phys. 1983, 51, 281-293. [CrossRef]

26. Arrese, A.L.; Ostáriz, E.S. Skinfold thicknesses associated with distance running performance in highly trained runners. J. Sports Sci. 2006, 24, 69-76. [CrossRef]

27. Brandon, L.J.; Boileau, R.A. The contribution of selected variables to middle and long distance run performance. J. Sports Med. Phys. Fit. 1987, 27, 157-164.

28. Wilson, B.R.; Olson, H.W.; Sprague, H.A.; Van Huss, W.D.; Montoye, H.J. Somatotype and longevity of former university athletes and nonathletes. Res. Q. Exerc. Sport 1990, 61, 1-6. [CrossRef]

29. Ross, W.D.; Marfell-Jones, M.J. Kinanthropometry. In Physiological Testing of the High Performance Athlete; Mac Dougall, J.D., Ed.; Human Kinetics: London, UK, 1991; pp. 223-308.

30. Durnin, J.V.; Womersley, J. Body fat assessed from total body density and its estimation from skinfold thickness: Measurements on 481 men and women aged 16 to 72 years. Br. J. Nutr. 1974, 32, 77-97. [CrossRef]

31. Katch, F.I.; McArdle, W.D. Prediction of body density from simple anthropometric measurements in college-age men and women. Hum. Biol. 1973, 45, 445-455.

32. Sloan, A.W. Estimation of body fat in young men. J. Appl. Physiol. 1967, 23, 311-315. [CrossRef]

33. Wilmore, J.H.; Behnke, A.R. An anthropometric estimation of body density and lean body weight in young men. J. Appl. Physiol. 1969, 27, 25-31. [CrossRef] 
34. Withers, R.T.; Craig, N.P.; Bourdon, P.C.; Norton, K.I. Relative body fat and anthropometric prediction of body density of male athletes. Eur. J. Appl. Physiol. Occup. Physiol. 1987, 56, 191-200. [CrossRef] [PubMed]

35. Siri, W.E. Body composition from fluid space and density. In Techniques for Measuring Body Composition; Brozek, J., Hanschel, A., Eds.; National Academy of Science: Washington, DC, USA, 1961; pp. 223-224.

36. Lee, R.C.; Wang, Z.; Heo, M.; Ross, R.; Janssen, I.; Heymsfield, S.B. Total-body skeletal muscle mass: Development and cross-validation of anthropometric prediction models. Am. J. Clin. Nutr. 2000, 72, 796-803. [CrossRef] [PubMed]

37. Carter, J.E.L.; Heath, B.H. Somatotyping: Development and Applications; Cambridge University Press: Cambridge, UK, 1990.

38. Billat, V.L.; Lepretre, P.M.; Heugas, A.M.; Koralsztein, J.P. Energetics of middle-distance running performance in male and female junior using track measurements. Jpn. J. Physiol. 2004, 54, 125-135. [CrossRef] [PubMed]

39. Kenney, W.L.; Hodgson, J.L. Variables predictive of performance in elite middle-distance runners. Br. J. Sports Med. 1985, 19, 207-209. [CrossRef] [PubMed]

40. Billat, V.; Lepretre, P.M.; Heugas, A.M.; Laurence, M.H.; Salim, D.; Koralsztein, J.P. Training and bioenergetic characteristics in elite male and female Kenyan runners. Med. Sci. Sports Exerc. 2003, 35, 297-304. [CrossRef] [PubMed]

41. Legaz, A.; Eston, E. Changes in performance, skinfold thicknesses, and fat patterning after three years of intense athletic conditioning in high level runners. Br. J. Sports Med. 2005, 39, 851-856. [CrossRef]

42. Oguri, K.; Zhao, L.; Du, N.; Kato, Y.; Miyamoto, K.; Hayakawa, M.; Kurokawa, J.; Nagasaki, S.; Matsuoka, T. Association of habitual long-distance running with the thickness of skeletal muscles and subcutaneous fat in the body extremities and truck in middle-aged men. J. Sports Med. Phys. Fit. 2004, 44, 417-423.

43. Pollock, M.L.; Miller, H.S.; Wilmore, J. Physiological characteristics of champion American track athletes 40 to 75 years of age. J. Gerontol. 1974, 29, 645-649. [CrossRef]

44. Vernillo, G.; Schena, F.; Berardelli, C.; Rosa, G.; Galvani, C.; Maggioni, M.; Agnello, L.; La Torre, A. Anthropometric characteristics of top-class Kenyan marathon runners. J. Sports Med. Phys. Fit. 2013, 53, 403-408.

45. Carter, J.E.L. (Ed.) Somatotypes of Olympic athletes from 1948 to 1976. In Physical Structure of Olympic Athletes. Part II Kinanthropometry of Olympic Athletes; Karger: Basel, Switzerland, 1984; pp. 80-109.

46. Brozek, J.; Grande, F.; Anderson, J.T.; Keys, A. Densitometric analysis of body composition: Revision of some quantitative assumptions. Ann. N. Y. Acad. Sci. 1963, 110, 113-140. [CrossRef]

47. Durnin, J.V.; Rahaman, M.M. The assessment of the amount of fat in the human body from measurements of skinfold thickness. Br. J. Nutr. 1967, 21, 681-689. [CrossRef] [PubMed]

48. Jackson, A.S.; Pollock, M.L. Generalized equations for predicting body density of men. Br. J. Nutr. 1978, 40, 497-504. [CrossRef] [PubMed]

(C) 2020 by the authors. Licensee MDPI, Basel, Switzerland. This article is an open access article distributed under the terms and conditions of the Creative Commons Attribution (CC BY) license (http://creativecommons.org/licenses/by/4.0/). 